\title{
PALEOGEOGRAPHY AND SEDIMENTATION DYNAMICS OF UJOH BILANG-BATUBELAH LIMESTONE MEMBER, UPSTREAM MAHAKAM RIVER, UJOH BILANG AREA, EAST KALIMANTAN PROVINCE
}

\author{
Moch. Indra Novian*and Herning Dyah Kusuma Wijayanti \\ Department of Geological Engineering, Gadjah Mada University, Yogyakarta, Indonesia
}

\section{Introduction}

The Kutai basin has become an object of interest for research, especially since after oil and gas potential are found in the basin. Many studies, from the order of tectonics, magmatism, stratigraphy to paleontology have been done here. Stratigraphical studies that have been performed provide general insights of the rock formation. However, a specific description at each stratigraphic measurement point has not been made. The research was conducted on rock outcrops along the upstream of Mahakam River close to Ujoh Bilang village up to Batubelah (Figure 1). The outcrops include the upper part of Batu Ayau Formation, Ujoh Bilang Formation and Batubelah limestone member which is located at the northwest side of Ujoh Bilang syncline with fairly fresh outcrop conditions, continuous, and its top and bottom can be well determined.

The Batu Ayau Formation represents MiddleLate Eocene rift deposit which is composed by coarse conglomeratic facies, sandstones, siltstones, coaly facies, and mudstones which were deposited in fluvial-deltaic to outer shelf environment (Wain et al, 1989, Abidin et al, 1993). During the sag phase in Oligocene time, deep-

${ }^{*}$ Corresponding author: M.I. NOVIAN, Department of Geological Engineering, Faculty of Engineering, Gadjah Mada University, Jl. Grafika 2 Yogyakarta, 55281, Indonesia. E-mail: indranovian@gmail.com ening of the basin caused a marine condition. The Ujoh Bilang Formation comprises of monotonous claystone, minor sandstone, partly calcareous. It also consists of two members, that is the foraminiferous limestone of Batubelah and Lenmuring sandstone. Both Batu belah and Lenmuring member of Ujoh Bilang Formation was deposited during early Oligocene and include in the Lower Ujoh Bilang Formation according to Wain et al (1989); Abidin et al, 1993. However, the new biostratigraphic data by Moss and Finch (1997) noted that Batu Belah Member was deposited during Late Oligocene. The Upper Ujoh Bilang Formation is recognized through its Late Oligocene age and its common association with olistolithic limestones and volcaniclastic debris flows.

\section{Methodology}

Recording of the vertical sequence of the rock was conducted in 1: 100 scale along the upstream of Mahakam River around the Ujoh Bilang village up to Batubelah. From these measurements, the resulting stratigraphic column was divided into 4 sections. This was carried out to provide a clearer paleogeography picture of that area. Section 1 recorded the rock order changes from the lower part of Ujoh Bilang Formation up to the transition to Batubelah limestone member. The second and third sections 


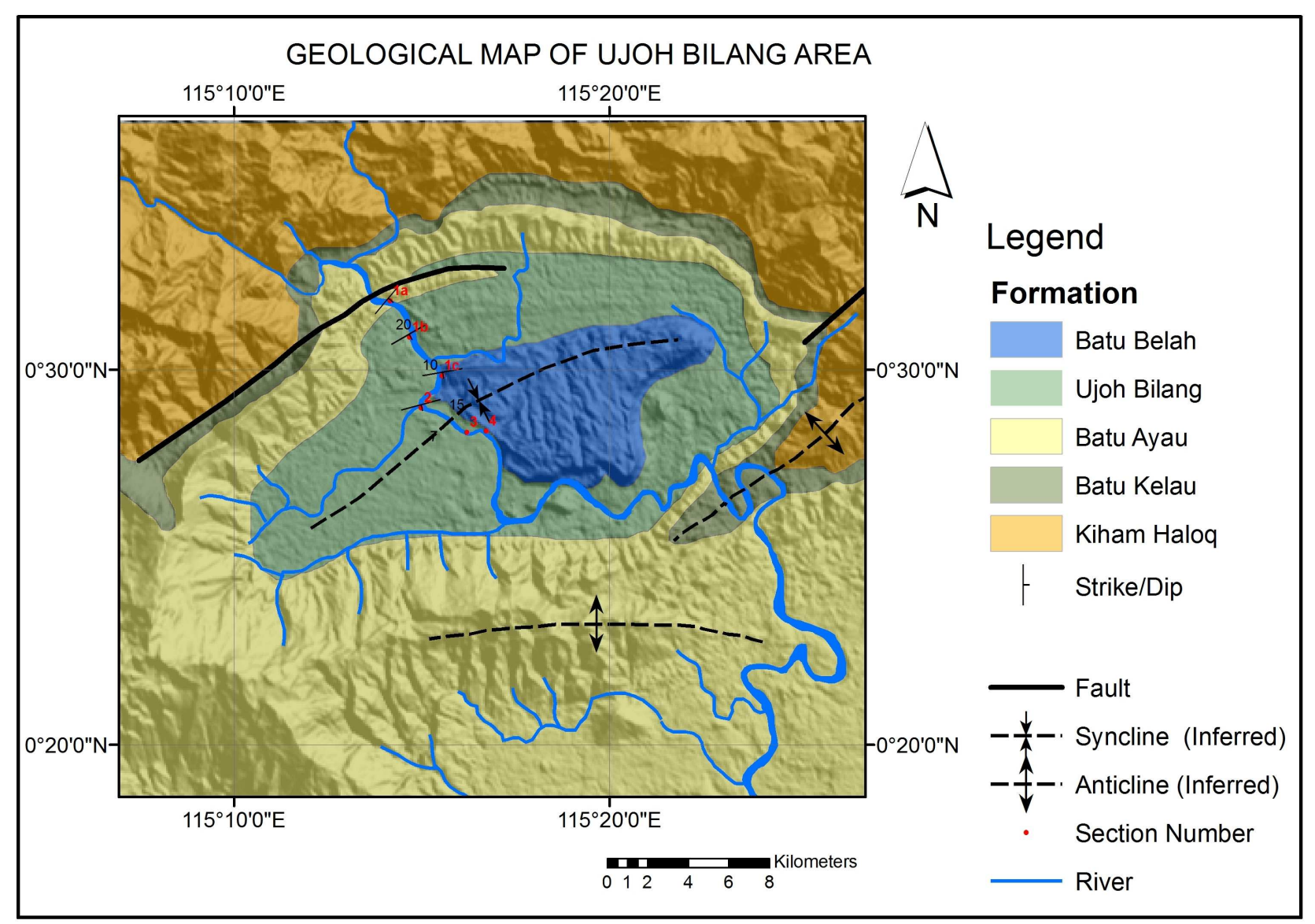

Figure 1: Geological Map of Ujoh Bilang area (Abidin et al, 1993 with modification), section 1-2 located at north western part of Ujoh Bilang Syncline axis, while section 3-4 located at south eastern. 
were done on the Southwestern tip of Ujoh Bilang syncline. Section 2 and 3 are younger than section 1 and there is a lag between measurements in section 2 until 3 to section 1 . Sections 2 and 3 have the same relative age. Section 4 is younger than section 1 but younger than section 2-3. Stratigraphic measurement of section 4 was conducted in Batubelah cliff. Several rock samples were taken for analysis. Three rock samples were taken to be analyzed with sieve method in order to see small foraminifera content, six samples were made into thin sections in order to view the content of minerals and fossils, especially foraminifera, and one rock sample was analyzed by smear slide method in order to view nannoplankton content.

\section{Facies}

The stratigraphic record resulting from field measurements combined with laboratory analysis can be divided into 12 facies (Figure 2). Description of each facies are given as follows:

Claystone facies (A). Claystone facies has dark grey color with iron concretions which often form their own concretion layers (Figure 3a). Thickness of this facies is around $4-15 \mathrm{~m}$ with bed thicknesses vary from $30 \mathrm{~cm}$ up to 300 $\mathrm{cm}$ and contain few foraminifera fossil. This facies is interpreted to be deposited in lagoonal area.

Interbedded fine sandstone and claystone facies (B). Interbedded fine sandstone and claystone facies has nearly similar thickness; about $10 \mathrm{~cm}$. Sandstone has brown to reddish brown color. Sedimentary structures which developed are parallel lamination, ripple, load cast and occasionally trace fossil ophiomorpha (Figure $3 b$ ), fine grained, grains supported, composed dominant by quartz and feldspar. Claystone has dark grey in color. This facies is interpreted was deposited in tidal area, especially in sub tidaloffshore.

Interbedded medium sandstone and claystone facies (C). Interbedded medium sandstone and claystone facies has nearly similar characteristics with the previous facies (facies B). The differences lie in grain size which composes the sandstone that is medium sand. This facies is interpreted was deposited in tidal area, especially in intra-tidal - sub tidal.

Sandstone facies (D). Sandstone facies consists of yellowish white sandstone with laminated-bedded, ripple and occasionally Ophiomorpha trace fossil. The grain size ranges from fine to medium sand, grain-supported, rounded, and composed dominantly by quartz and feldspar. Thickness of this facies is about 6 $-11 \mathrm{~m}$ with bed thickness range from $10-20$ $\mathrm{cm}$. This facies is interpreted to be deposited in shallow marine environment, especially in shore face in fair weather wave zone.

Claystone with fine sandstone intercalation facies (E). Claystone with fine sandstone intercalation facies is $19 \mathrm{~m}$ thick with bed thickness ranging from $30 \mathrm{~cm}$ to $150 \mathrm{~cm}$. Claystone is dark grey without Foraminifera content. Sandstone is brown in color with bedded sedimentary structure, fine sand grain size, grain-supported, rounded, and composed by quartz and feldspar. Thickness of sandstone varies from $10 \mathrm{~cm}$ to $30 \mathrm{~cm}$. This facies is interpreted to be deposited in transition zone between shore face-offshore, that is, between fairstorm weather wave base zone.

Claystone with large foraminifera facies (F). Claystone with large foraminifera facies is grey in color (Figure 3c), massive in the lower part. In the upper part it has thin bed that curves downward and composed by large foraminifera with good grain orientation. Towards the top, foraminifera content increases with more random orientation. Large foraminifera are dominated by lenticular form. This facies is interpreted to be deposited in a shallowing upward offshore area.

Muddy allochem limestone facies (G). Muddy allochem limestone facies has light grey color, consists of large foraminifera that mixes with algae in the lower part, and toward the top gradually changes into large foraminifera with 


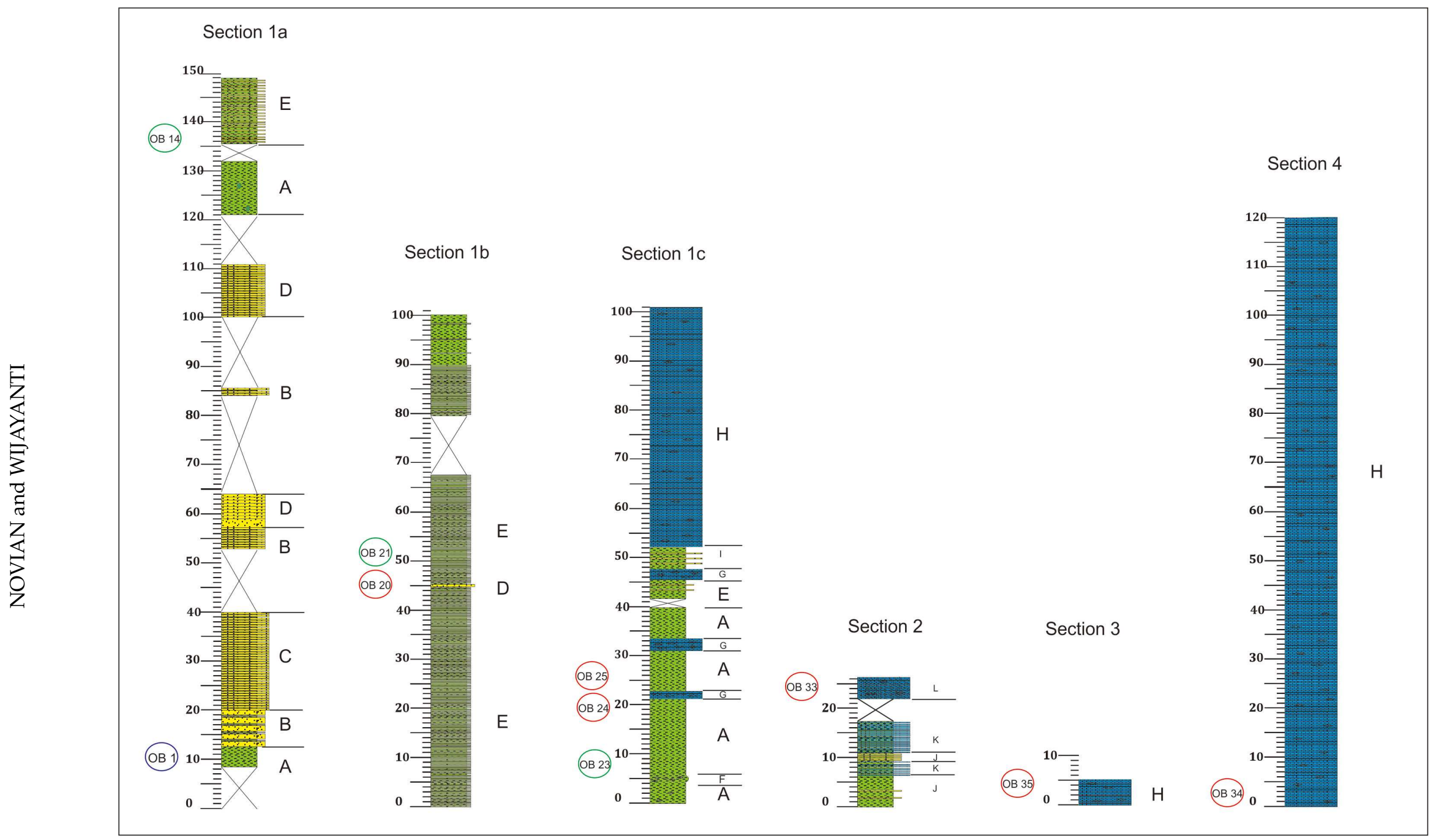

Sample
(B1) Nanno fossil
(6823. Foraminifera fossil
(6833) Thin section

Figure 2: Facies in study area. Coarsening and shallowing up ward pattern are recognize from vertical succession. 

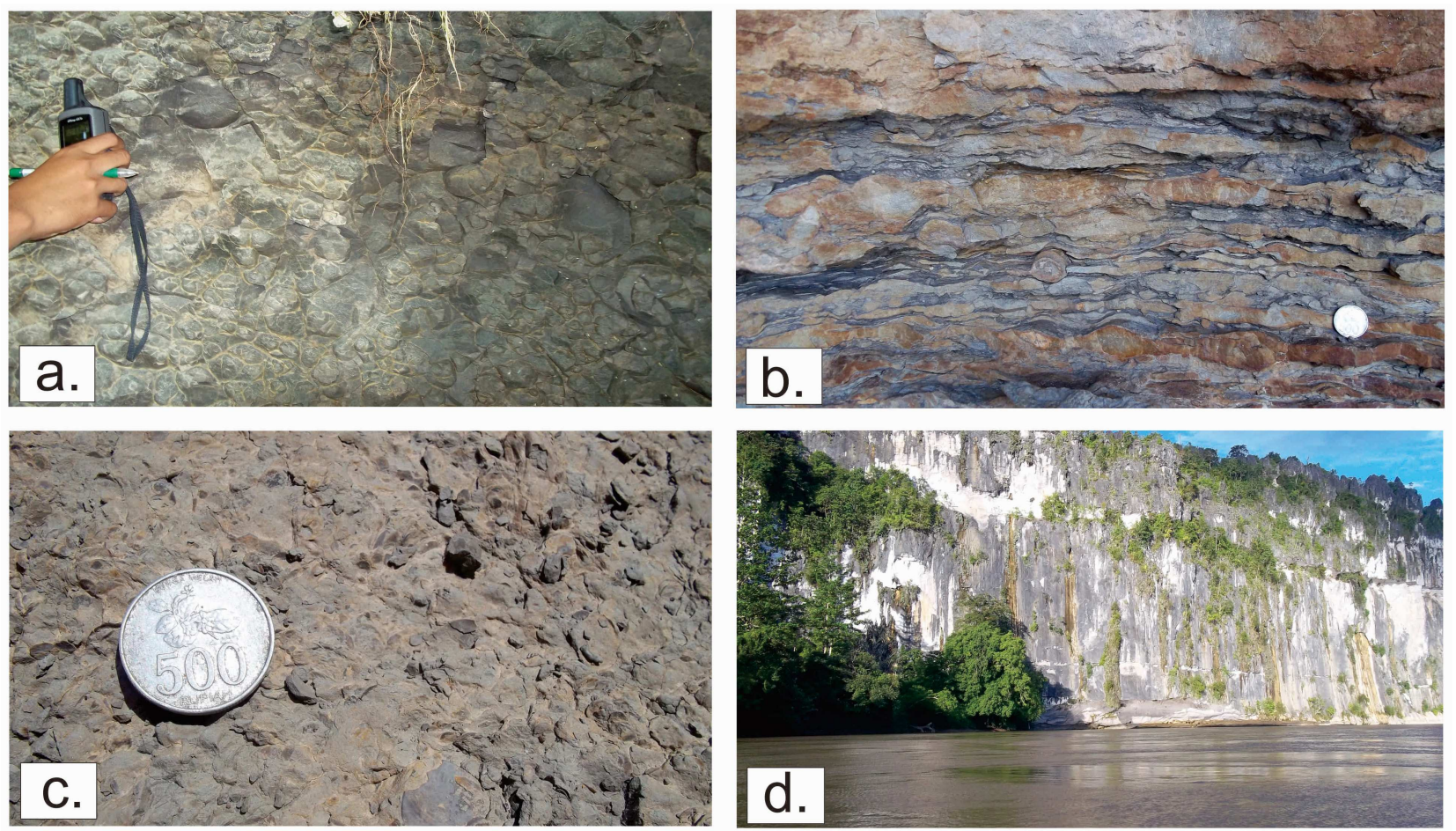

Figure 3: Several outcrop of facies in study area: a) Facies A: Black clay; b) Facies B: Interbedded fine sandstone with claystone; c) Facies F: Claystone with large foramiinfera; d) Facies H: Foraminiferal float-rudstone of Batu Belah limestone member.

lenticular form. This facies is composed by large foraminifera such as Heterostegina borniensis, Nummulites, Eulepidina and Miliolina, along with pelecypoda, red algae and coral. This facies is interpreted to be deposited in offshore area, especially in the fore reef.

Foraminiferal float-rudstone facies (H). Foraminiferal float-rudstone facies has yellowish white color, bedded, random grain orientation, mud-grain supported, grain size larger than $2 \mathrm{~mm}$, composed by large foraminifera, algae, pelecypoda, and bed thickness range from $40-100 \mathrm{~cm}$ (Figure 4d). This facies is interpreted to be deposited in fore reef slope.

Interbedded claystone and coarse sandstone facies (I). The facies consists of interbedded claystone and coarse sandstone facies. Claystone is dark grey in color, minor large Foraminifera fossil content with bed thickness averagely 30 to $40 \mathrm{~cm}$. Sandstone is brown in color, massive, mud-grains supported, coarse sand grain size (2-4 mm), composed by quartz and large foraminifera fragment. This facies is interpreted to be deposited in offshore with sediment source came from terrigenous source and reef.

\section{Interbedded foraminiferal sandstone and claystone facies (J). Interbedded foraminiferal sandstone and claystone facies has nearly similar bed thickness, about $10 \mathrm{~cm}$. Sandstone is brown - reddish brown in color, fine grain size, grain supported with grain dominantly composed by quartz and large foraminifera. Paralel lamination and load cast are the most developed sedimentary structure. Claystone is dark grey in color. This facies is interpreted to be deposited in open platform.}

\section{Interbedded rudstone and claystone facies}

(K). The facies consists of grayish white limestone, grain-mud supported. Grains consist of large foraminifera, algae and minor quartz with $10 \mathrm{~cm}$ thickness for each bed. Claystone is dark grey in color with thickness of each bed ranging 
from $10 \mathrm{~cm}$ to $20 \mathrm{~cm}$. This facies is interpreted to be deposited in reef flat - open platform.

Rudstone facies (L). The rudstone facies is white-grayish white in color, has tangential cross-bedding structure, and grain-supported. Grains are composed by coral, red algae fragment, large foraminifera (Borelis, Austrotrilina, Miogypsinoides dan Amphistegina), some micrite that has been altered into calcite, thickness of each bed ranges between 100-150 cm. This facies is interpreted to be deposited in back reef or reef flat.

\section{Paleogeography and Dynamic Sedi- mentation}

Based on the examination of facies developed in the study area, it can be concluded that there have been some changes of paleogeography during the deposition of Ujoh Bilang Formation. This is reflected in the depositional environment shift seen in the deposited facies. At the lower part of this formation (initial of section 1), the paleogeography still changed from the Batu Ayau paleogeography setting toward the Ujoh Bilang. These changes occur gradually which reflected on the gradational facies changes. At the beginning, the facies is dominated by interbedded sandstone and claystone, then begin to turn into interbedded claystone and sandstone, then claystone, and finally is closed by limestone facies (Figure 4).

The pattern that is developed in section 1 is coarsening and shallowing upward. The pattern can be seen from the change of facies $A$ to $B$ then $C, B-D, A-E-B, A-F, A-G, A-E-$ $\mathrm{H}$ and $\mathrm{I}-\mathrm{H}$. In facies $\mathrm{A}-\mathrm{B}-\mathrm{C}, \mathrm{B}-\mathrm{D}$ and $\mathrm{A}-\mathrm{E}-$ $B$, the depositional environment changed from deeper environment to mainland, that is, from offshore in a lagoonal area to tidal area. Initially, restricted or closed lagoon was formed. By time, it became more open. This is indicated by the presence of dominant mudstone with iron concretion, indicating reductive condition. The presence of carbonate-shelled fossils, especially foraminifera and nannofosil was not found of the prepared three rock samples (OB 1, 14 and 21). Towards the top, lagoon area was more open, shown by the open looping facies A-F, A-G, A-E-H and I-H. Claystone facies that exist in these facies contain many large foraminifera fossil and start to be intercalated by limestone. In claystone that is intercalated with limestone (OB 23), the amount of small bentonic foraminifera is greater than planktonic and dominated by Quenquiloculina teenagos. The presence of Quenquiloculina teenagos indicates lagoonal environment, but the presence of other foraminifera fossils indicate marine conditions (Boudagher-Fadel, 2008). This strengthens the influence of the marine environment into the lagoon where the rock was formed. Age of rock based on the content of planktonic foraminifera (Globigerina ampliapertura Bolli, Globigerina pseudoampliapertura Blow \& Banner, Globigerina tapuriensis Blow \& Banner, Globigerina pseudovenezuelana Blow \& Banner, Globigerina and Globorotalia corpulenta Subbotina shows P18/19 or comparable with Tc$\mathrm{d}$ in larger foraminifera chart (Lunt and Allan, 2004).

Towards the end of the section, the environmental condition become increasingly heading towards open sea, hence very supportive for reef growth (facies $\mathrm{H}$ ). Reef initially grew as biostrome wherein composed of shell material both of larger foraminifera, corals, algae and pelecypoda which are derived from surrounding environment. Formed reef did not grow i n sufficient speed hence there was no mound morphology. Instead, it only formed a horizontal bedding which thinned toward the edge. The slower reef growth compared to increasing accomodation space is thought to be the cause of growth halts which then the remainings were covered by sediment materials of terrestrial origin. In the end, reef organisms began to offset the sea level rise, forming a thick layer of limestone at the end of section 1 and included in Batu Belah Limestone Member. Based on larger foraminifera (Heterostegina, Eulepidina, Nummulites, minor number of Miliolina), corals, algae and pelecypoda (OB 24 and OB $25)$, this limestone is interpeted to be formed in reef front (Figure) and deposited in the early Oligocene (Tc-d) (Lunt and Allan, 2004).

Like section 1, section 2 have coarsening and 

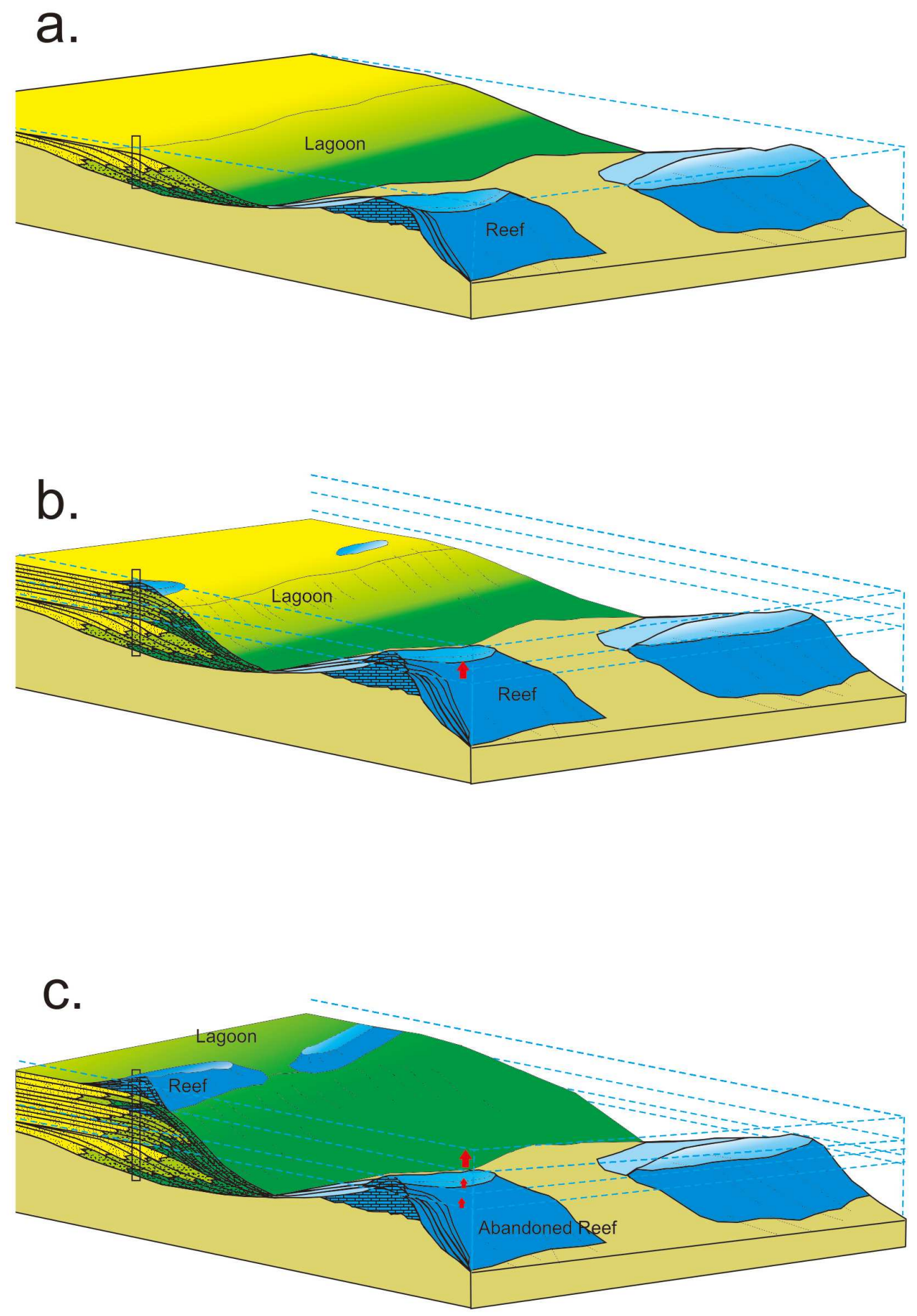

Figure 4: Paleogeography change during Early to Late Oligocene of Ujoh Bilang Formation to Batu Belah limestone member in Upstream Mahakam River. a) Intial deposition of Ujoh Bilang Formation in lagoon area; b) Sea level rise cause the environment become marine; c) Reef can catch and exceed rate of sea level rise. 
shallowing upward stratigraphic pattern. The pattern can be seen from the change of facies $\mathrm{J}$ into facies $\mathrm{K}$ which later turns into facies $\mathrm{L}$. Facies $\mathrm{J}$ was deposited in open platform area at back reef. Therefore, it often had reef material debris in form of larger foraminifera shells. Facies $\mathrm{J}$ that is replaced by facies $\mathrm{K}$ indicates that the environment increasingly became shallower toward reef flat - open platform area. After that, there was an addition of accommodation space, followed by the deposition of facies $\mathrm{J}$ and $\mathrm{K}$. After the deposition of facies $\mathrm{K}$ there is a blank zone on the stratigraphic measurement which is then closed by the formation of facies $L$ which was deposited on the back reef flat. Based on the strike and dip of bedding, section 2 is younger than section 1 . Sample OB 33 that was taken from facies L contains larger foraminifera such as Borelis, Austrotrilina, Amphistegina, and Miogypsinoides which shows Late Oligocene age (Te2-3) (Lunt and Allan, 2004).

Section 3 and section 4 is located in the southeast of the Batu Belah syncline axis. Section 3 is $5 \mathrm{~m}$ thick in total, individual bed thickness ranging from $30-100 \mathrm{~cm}$, and included in facies $\mathrm{H}$. The larger foraminifera content in sample OB 35, such as Heterostegina, Neorotalia mecatepecensis, Eulepidina, Amphistegina and Austrotrillina shows that the lithology of facies $\mathrm{H}$ was deposited in reef front at the Late Oligocene (Te1) (Lunt and Allan, 2004). Beside larger foraminifera, the lithology was also composed by other benthic organisms such as pelecypoda and also quartz which has terrestrial fragments origin. This indicates the terrestrial origin of sediment supply was still ongoing, but not to interfere the reef growth.

Section 5 is stratigraphically above section 4 , but turns to be separated by the lack of stratigraphic measurement with unconsiderable thickness. The thickness of facies $\mathrm{H}$ in this section is up to 120 mete that forms a cliff with almost horizontal bedding. The rock samples on the lower part of this section (OB 34) shows larger foraminifera contents; the abundance of Borelis, Austrotrillina, Eulepidina, and Amphistegina shows that rocks was deposited on the reef flat or backreef at Late Oligocene (Te) (Lunt and Allan, 2004).

\section{Discussion}

Based on the strike and dip of the rock and larger foraminifera content observed in each section, correlation can be performed on section 4 . Section 1 is the oldest section which was deposited on this research traverse. Early Oligocene age was determined from the rock sample in the middle of this section. Age of rock at the beginning of this section can only be concluded to be not younger than Early Oligocene. The absence of small foraminifera and nannofossil due to reductive lagoonal-tidal environment causes difficulty for age determination. Furthermore, section 3 was deposited above the section 1 with age Te1, followed by deposition of section 2 and 4 .

Paleogeographic changes observed from section 4 shows that the changes were gradational. It started from lagoonal environment which is shallow into tidal areas and this occured repeatedly. It then turned into lagoon, and then changed into reef front. Initially, the increasing of accommodation space cannot be countered by the growth of reef-forming organisms so that reef eventually died and covered with siliciclastic materials. However, in the end, the reef can offset the accommodation space increase; the growth was even beyond the space increase. This is indicated by rock deposition which comprises that section 2, 3 and 4 were deposited on reef flat. Youngest age that can be identified in rock samples is from the central part of section 2, which is Late Oligocene (Te2-3).

\section{Conclusions}

1. Ujoh Bilang Formation was deposited in lagoon-tidal environment.

2. The formation changes from Ujoh Bilang to Batu Belah limestone member occured gradually following the sea level rise. The depositional environment was shifted from lagoon to marine and accompanied with growth of reef organisms builder which exceed rate of sea level rise. 
3. Ujoh Bilang Formation was deposited not younger than Early Oligocene, while Batu Belah limestone member was occured during Early - Late Oligocene.

\section{Acknowledgements}

Acknowledgements are addressed to LKFT UGM for their permission to present this paper. The content of this paper were part of a regional Upper Kutei Basin study conducted by LKFT UGM-PT ATI.

\section{References}

Abidin H.Z, Pieters P.E, and Sudana D. (1993) Geological Map the Muara Longpahagai Sheet area, Kalimantan, Scale 1:250.000, Geological Research and Development Centre, Bandung.
Boudagher-Fadel, M.K. (2008) Evolution and Geological Significance of Larger Benthic Foraminifera, Elsevier, Amsterdam, Netherland.

Lunt P. and Allan T. (2004) A history and application of larger foraminifera in Indonesian Biostratigraphy, Calibrated to Isotopic Dating, GRDC workshop on micropaleontology, The Museum of the GRDC, Bandung.

Moss S.J. and Finch E.M. (1997) Geological Implication of new biostratigraphic data from East and West Kalimantan, Indonesia, Journal of Asian Earth Sciences 15: 489-506.

Moss S.J and Chambers J.L.C. (1999) Tertiary facies architecture in the Kutai Basin, Kalimantan, Indonesia, Journal of Asian Earth Sciences 17: 157181.

Wain, T. and Berrod, B. (1989) The Tectonic Framework and Paleogeographic Evolution of The Upper Kutei Basin, Proceedings of the Indonesian Petroleum Association 1: 55-78. 